\title{
"VENI A SACAR A LA PERRA QUE HAY EN VOS": PEDAGOGÍAS DE LA SEDUCCIÓN. MERCADO Y NUEVOS RETOS PARA LOS FEMINISMOS
}

\author{
Silvia Elizalde \\ Karina Felitti \\ CONICET - Universidad de Buenos Aires
}

\section{RESUMEN}

En un escenario social de creciente mercantilización del deseo, reconfiguración de los códigos erótico amorosos y expansión de las consignas feministas de "liberación sexual", el artículo analiza la producción y circulación de un conjunto de "pedagogías de la sexualidad" destinadas a mujeres heterosexuales. El trabajo se basa en la exploración y análisis de sitios web y publicaciones que enseñan técnicas de seducción y erotismo y, principalmente, en un relevamiento etnográfico en dos "escuelas de seducción” para mujeres de la ciudad de Buenos Aires. Los hallazgos del estudio cuestionan ciertas comprensiones establecidas sobre la "liberación sexual" femenina y proponen una interpretación sobre una zona poco estudiada del mercado del sexo, así como de las relaciones que se construyen entre erotismo, mercado y sexualidad en la actualidad.

\section{PALABRAS CLAVE}

Pedagogías de la sexualidad, Seducción, Mercado, Liberación sexual, Feminismos

\section{ABSTRACT}

In a social scenario of commodification of desire, reconfiguration of erotic and love codes and spreading out of feminist slogans about "sexual liberation", this article analyzes the production and circulation of "pedagogies of sexuality" aimed to heterosexual women. The study is based on the exploration and analysis of websites and publications that teach techniques of seduction and eroticism and on 
an ethnographic survey into two "schools of seduction" for heterosexual women in the city of Buenos Aires. Its findings challenge hegemonic understandings about the women sexual liberation and propose an interpretation of an unexplored zone of sex market and the relationships that it creates.

KEY WORDS

Pedagogies of sexuality, Seduction, Marketplace, Sexual liberation, Feminisms 


\section{INTRODUCCIÓN}

Tentarte es el nombre comercial de un emprendimiento de "coaching de seducción" que lleva adelante una atractiva mujer argentina de 40 años, quien se presenta como la "fundadora de la Primera Escuela de Seducción en Latinoamérica" y promociona sus servicios en dos sitios de internet conectados entre sí, www.coachindeseducción. com.ar y www.tentarte.com.ar. En uno de ellos se ve el anuncio de un "Taller de striptease y make up hot", con la imagen de una pin-up de los años cincuenta, vestida con ajustada lencería roja, que sonríe divertida mientras mordisquea suavemente un látigo enfundado en raso. En el texto se lee lo siguiente:

No importa el cuerpo, ni la edad ni la ocupación... sólo interesan tus ganas de divertirte, de verte y sentirte como una verdadera sex symbol, aprendiendo a moverte y a provocar. Aprenderemos juntas coreos [coreografías] de strip dance para que saques tu lado más sexy y atrevido y lo dejes con la boca abierta...ya! También vamos a elegir entre las distintas opciones de vestuario para desvestirnos con sensualidad y estilo. Incorporaremos en este taller trucos de maquillaje y tips fundamentales para adquirir un conocimiento completo y super hot para esa noche especial... que puede ser hoy. ¿Qué estás esperando para convertirte en una verdadera striper? ¡Te espero! (www.tentarte. com.ar, 2013).

Bajo la consigna tácita de que "a seducir se aprende", esta escuela ofrece distintos talleres y cursos para mujeres, como el "Taller integral de seducción", el de "Lenguaje de un cuerpo sexy" o el de "Aceptación y autoestima sexual", entre muchos otros. Cada uno, a su modo, promete brindar información, consejos y guías para "aprender a desplegar nuestra capacidad de seducción" y "vincularnos a la hora de la elección de pareja", así como para "activar nuestro potencial sexual y erotismo a través de la danza, la corporalidad y el juego como herramienta". La propuesta invita a "descubrirte y descubrir al otro", "sacar tu lado más sexy", "aprender como una profesional" y "sacar la diablita que hay en vos". Se espera que descifrando el lenguaje del cuerpo y "los misterios de la seducción" emerja la "diosa sensual" que habita en cada mujer. O más directamente, como arenga la coach en los talleres, "salga la perra que hay en vos".

Promesas similares anuncia desde su página web otra reconocida escuela de este tipo, también autoproclamada como pionera: "la primera Escuela de Sexo de Buenos Aires." Se trata de $P K$, creación de la "asesora en juegos eróticos y masajista profesional”, Paola Kullock. El nombre comercial alude obviamente a las iniciales de su creadora (PK), pero es también una invitación explícita y provocadora - "peca"- que cuestiona la asociación entre "sexo y "pecado" propia de los discursos de inspiración cristiana. En sus "talleres de seducción y sensualidad con el cuerpo", Kullock convida a las mujeres a conocer "todos los secretos de las profesionales [del sexo] para que los uses en la intimidad de tu hogar", y de esta forma "te sientas y veas segura, femenina, sexy y seductora", ya que "todas podemos mostrarnos y sentirnos bellas para él" (www.pkescueladesexo.com.ar, 2013).

Si bien los materiales analizados en este artículo corresponden a la Argentina, la existencia de estos espacios de coaching sexual se enmarca 
en un fenómeno global en crecimiento, que expande las fronteras del mercado del sexo. A esto contribuye la oferta de bienes y servicios de una parte significativa de la industria cultural que se plasma en innumerables libros, revistas y películas consagradas al erotismo y la "sexualización" femenina. Claro ejemplo de ello es el rentable nicho instaurado por la trilogía literaria Las 50 sombras de Grey y sus subproductos convergentes (Illouz, 2014). En este contexto, resulta evidente el interés por incluir como consumidoras estratégicas de dicho mercado a las "mujeres comunes", definidas así por contraste con las trabajadoras sexuales, las prostitutas, las bailarinas de striptease y/o las vedettes, incluso a fuerza de obliterar el carácter abiertamente polémico de estos posicionamientos identitarios y de los diversos componentes del llamado "mercado del sexo" (Bernstein, 2007).

En esta línea, la conversión de la pornografía en una narrativa social generalizada y el crecimiento exponencial de su consumo - así como el de los juguetes sexuales - por parte de las mujeres situadas en el espacio doméstico (las "mamis"), constituyen tendencias centrales de un proceso que Eva Illouz define como de "pornificación de la cultura". ${ }^{1}$ Desde su perspectiva, dicho fenómeno representa un impulso inédito para la formación de "una nueva cultura de la autonomía sexual femenina" (Illouz, 2014: 48-50). Gregori, por su parte, resalta el carácter coproductivo de este ascendente campo

1 La rutina de Vixen Workout (www.vixenworkout.com, 2014) o la "gimnasia de las zorras", que se practica con zapatos de plataforma, maquillaje y ropa sensual, y hace furor en Nueva York, o el éxito de las academias de pole dance en la ciudad de México (www.poledanceschool.com. $\mathrm{mx}$ ), son otros ejemplos de este fenómeno extendido en Occidente. sexual, en tanto se da una retroalimentación entre ofertas de mercado e iniciativas de las mujeres en la revalorización de bienes eróticos para sus vidas (2011). Por supuesto que esto no niega que en muchos espacios persista la sanción social sobre aquellas que se muestran con una vida sexual "activa" y/o desafían la heteronormatividad - decisiones que pueden valerles incluso la propia vida-; más bien señala que un número importante de mujeres cuenta hoy con márgenes culturales más holgados que los que tuvieron sus propias madres para pensarse como seres deseantes. Ser madre sexy y esposa que en la intimidad juega a ser puta, o entrenarse y producirse (como bien de consumo) para ser "experta en la cama", son opciones culturalmente disponibles $-\mathrm{y}$ deseables - para numerosas mujeres.

Junto a esta tendencia, en el contexto específico argentino, el entramado normativo en materia de género y sexualidad de los últimos diez años puede pensarse también como un factor que incide en este escenario cultural y erótico emergente. El poder (y el deber de) hablar abiertamente sobre el placer como dimensión valiosa y positiva de la sexualidad (tal como plantea la ley de Educación Sexual Integral), desnaturalizar la asociación tradicional entre sexualidad y reproducción (Ley de Procreación Responsable, cobertura de tratamientos de reproducción asistida para parejas del mismo sexo) o postular la autonomía en los modos de expresar orientaciones y búsquedas alrededor del deseo sexual y de conformar pareja (Ley de Identidad de Género y Ley de Matrimonio Igualitario) son algunas de las políticas públicas vigentes. Un horizonte legislativo de avances pero con un límite claro respecto de la autodeterminación del cuerpo 
femenino debido a la resistencia política a debatir y promulgar una ley que legalice el aborto.

En un contexto en el que las redes sociales, los sitios de citas en internet y las aplicaciones para celulares que concretan encuentros en tiempo real mediante un GPS parecen hegemonizar el mercado de los encuentros erótico-amorosos, la existencia de espacios y de productos consagrados a la "enseñanza de la seducción" para mujeres heterosexuales resulta, como mínimo, un sugerente diacrítico cultural desde el cual leer algunas de las transformaciones que están teniendo lugar en el campo de la sexualidad $y$ en sus (des)bordes sociales y subjetivos en el despunte del siglo XXI. De allí que este circuito de bienes y servicios hot para "mujeres comunes" condensen tanto ambivalencias y ansiedades colectivas (que estos espacios prometen disolver mediante el logro personal de resultados certeros y eficaces), como preguntas sociológicas y políticas de importancia. Entre ellas, aquellas que refieren a las derivas del deseo y el erotismo contemporáneos, la reestructuración de la heteronormatividad en los renovados escenarios de la cultura del consumo y el lugar de las mujeres en esta nueva economía libidinal. $\mathrm{Al}$ respecto, nos preguntamos en qué medida tener (mucho) sexo y "hacerlo bien" constituye hoy un logro o, bien, una nueva imposición para las mujeres.

El presente estudio problematiza el estatuto "pedagogizador" de estas experiencias de coaching sexual para mujeres, sus recetas para la conquista de un varón y sus consejos para dar y obtener placer como parte de un aprendizaje integral que promete sacar a la "perra" sexual que habita en cada mujer. A este respecto, nos preguntamos acerca del lugar que estas pedagogías ocupan frente a las conquistas y deudas pendientes de la equidad de género y sobre la interpelación que instalan a ciertas comprensiones establecidas sobre la "liberación sexual" femenina, sobre todo a aquellas que reivindican la vía individual de emancipación y la polivalencia del deseo (Kelly, 2005; Illouz, 2014), de fuerte pregnancia entre las jóvenes (Elizalde, 2015), de cara a las "nuevas formas de contrato sexual" en curso (McRobbie, 2009: 2). Por pedagogías de la sexualidad (Lopes Louro, 1999) entendemos el conjunto de acciones y omisiones, permisos y prescripciones de orden ideológico que dan sentido, modelan y justifican intervenciones regulatorias sobre los cuerpos y las sexualidades, moralizan ciertas experiencias, recorridos y elecciones biográficas en estas materias, y efectivizan su impacto a partir de un lenguaje perfomativo que, al nombrar la diferencia, o silenciarla, le da forma, existencia, inscripción o exclusión, en una grilla de inteligibilidad sociosexual hegemónica (Elizalde, 2014).

A partir de los aportes del materialismo cultural para pensar el funcionamiento ideológico de la discursividad social (Hall, 2010), las teorías de género y feministas y los estudios sobre sexualidades, indagamos en las lógicas de promoción, transmisión y aprendizaje de estos guiones de seducción para mujeres heterosexuales, en tanto instancias de constitución de un saber erótico como clave del éxito personal y con los hombres. Buscamos, asimismo, preguntarnos por los alcances que tienen, en estos espacios de "fraternidad femenina", las demandas de algunos feminismos con respecto a deconstruir radicalmente el discurso romántico y las fantasías sexuales que alentaría el patriarcado, bajo el argumento de que 
ambos elementos subyugan la autodeterminación de las mujeres.

La metodología utilizada combina el análisis comunicacional de discursos, estéticas y materiales de orden textual, audiovisual y multimedia (páginas web, avisos de promoción, notas periodísticas, videos, fotografías, etc.), con el relevamiento etnográfico durante octubre, noviembre y diciembre de 2013, en algunos espacios del circuito argentino del erotismo para mujeres, de modo prioritario, en tres talleres de seducción femenina brindados por dos "escuelas de artes eróticas" de la ciudad de Buenos Aires - las mencionadas Tentarte y $P K$-, y en sus showrooms de lencería hot. Como relevamiento adicional de contexto, realizamos también observaciones en una feria erótica-sexual ("SexpoErótica") cuya novena edición se realizó en Córdoba, ciudad capital de la provincia argentina del mismo nombre, en abril de 2014. ${ }^{2}$ El trabajo de campo en los talleres requirió el involucramiento del propio cuerpo como herramienta de investigación

2 Durante tres días consecutivos, de las 6 de la tarde a las 5 de la mañana, el evento ofreció "instancias para el diálogo, el juego, la experimentación y el aprendizaje" mediante exposiciones, charlas con terapeutas sexuales, shows, juegos y venta de productos relacionados con la sexualidad y el erotismo. La programación incluyó talleres exclusivos para mujeres sobre orgasmo y masturbación femenina, tupper sex e "intim coach", así como un "campeonato para fingir orgasmos" y competencias de "Kamasutra Express", en la que resultaba ganadora la pareja que formara delante del público la mayor cantidad de posiciones sexuales en un minuto, estando siempre vestidos. La actividad de cierre estuvo a cargo de la sexóloga Alessandra Rampolla, cuyos libros y programas televisivos alcanzan alta repercusión en Latinoamérica, y de Paola Kullock, cuya propuesta de "escuela de sexo" analizamos en detalle en este trabajo (www.sepoerotica.com.ar, 2014). y vector de conocimiento, a partir de nuestra implicación carnal (Wacquant, 2006) en dinámicas de entrenamiento en movimientos, posturas y danzas de corte erótico. Poner el cuerpo y ser conscientes de su presencia y lectura sexuada por parte de otros/as, para explorar un tema que en el ámbito académico puede resultar banal, innoble o de dudosa ética, constituyó un sugerente desafío. Se generó así un reto no sólo contra los preconceptos que rigen en el campo científico las reglas históricamente variables de demarcación de los objetos "dignos" de estudio, sino también una desestabilización de los propios prejuicios y miedos asociados a la experiencia sexual como construcción simultáneamente individual y social (Kulick, 1995).

\section{SOBRE LAS MUJERES, LA LIBERACIÓN SEXUAL Y EL "MARGEN DE MANIOBRA"}

En un señero análisis de mitad de los años ochenta, Julia Kristeva ya delineaba las coordenadas de las nuevas tramas intersubjetivas asociadas al campo de la intimidad. Tramas que hoy están exponencialmente agudizadas por la ubicuidad de las nuevas tecnologías en la vida cotidiana y por la reconfiguración psicosocial puesta en marcha a partir de ellas. Según Kristeva, el imperio del individualismo vigente sume a la sociedad occidental en una sistemática fragmentación de los vínculos y en una radical transformación del amor, que llega incluso a su misma negación (en Collin, 1991). El discurso amoroso parece haber perdido, pues, un eje aglutinador que habilite la circulación de un código erótico-afectivo compartido entre mujeres y varones. Para algunos, en su lugar se impone la 
idea de "amor líquido" en el que prevalece el deseo y su fin consumista, antes que el sentimiento y sus motivaciones solidarias, dando lugar a relaciones que se definen en términos de costo y beneficio, de inversión y riesgo (Bauman, 2005).

Ante la dispersión y confusión que esto genera, cobran creciente importancia aquellas propuestas que invitan a la reconciliación con uno/a mismo/a como salida de la angustia, y a la búsqueda de caminos reflexivos y/o experimentales de autopromoción y estima. De ahí el éxito de la autoayuda en sus diferentes formatos masivos (literatura, programas de TV, espacios de formación/ capacitación, revistas), la vuelta a religiosidades y espiritualidades ancestrales como contestación al racionalismo a ultranza, la nueva "conciencia" sobre los hábitos dietarios, la meditación o el yoga, entre muchas otras variantes del retorno a la "naturaleza" y al "ser interior". En alguna medida las "escuelas de seducción" forman parte de este repliegue (no siempre reflexivo) sobre el self (Giddens, 1998), con impactos diferenciales para varones y mujeres.

Por otro lado, las terapias psicoanalíticas y las producciones filosóficas, antropológicas y sociológicas recientes sobre el vasto campo de las emociones constituyen caminos de intelección, desde la ciencia y los saberes cultos, en torno de las dinámicas intersubjetivas y la trama de los afectos en la sociedad del capitalismo tardío. Lo interesante es que estas producciones también pueden ser reapropiadas por los públicos en clave de autoayuda. En esta línea, Eva Illouz (2012b), quien procuró respuestas sociológicas a la difícil pregunta de ¿por qué duele el amor?, título de uno de sus libros, advirtió que aunque esa obra no era de autoayuda, ni ella ni nadie podían controlar que fuera comprada con ese objetivo o terminara funcionando de esa forma. Como parte de su crítica a la patologización del sufrimiento la autora señala: "pensamos que curarnos significa cumplir con un conjunto de deberes, en adoptar un nuevo conjunto de conductas o modo de pensamiento que nos harán más felices. Yo pienso que lo que nos alivia de nuestro sufrimiento es algo a la vez más pequeño y más grande. Es comprender, solamente comprender, qué es lo que verdaderamente nos hace más infelices" (Illouz, 2012b).

¿Cómo se ubican las mujeres en estas nuevas condiciones? Sabido es que parte de las transformaciones en los roles de género y en las pautas de moral sexual ocurridas en la segunda mitad del siglo XX han hecho posible que una cantidad significativa de mujeres pueda impugnar en sus propias biografías, la asociación ineluctable entre sexualidad y procreación, la domesticidad como principal destino y la condena moral por la procuración del goce erótico. Evidentemente estos cambios no han afectado a la totalidad de las mujeres, dada la heterogeneidad de contextos y experiencias en las que clase, raza/etnicidad, género, sexualidad, edad, religión y otras marcas de la diferencia se intersectan entre sí (Viveros, 2009). Las heterosexuales, blancas, de clase media, educadas y/o profesionales, nacidas en países desarrollados y con inserción en el mercado formal de trabajo son quienes más han experimentado - previsiblemente, por la impronta clasista, racista y heteronormativa de la matriz patriarcal-, una mayor autonomía económica y libertad sexual. Muchas de ellas han logrado prescindir de la pareja heterosexual 
como unidad de producción para su supervivencia, cuestión clave puesto que cuando existe dependencia económica, ella constituye un duro obstáculo para el logro de independencia emocional de las mujeres (Esteban, 2011; Coria, 2014 y 2011). Con todo, una mayor autonomía económica de este grupo tampoco las "libera" totalmente. Más bien, suele arrojarlas a un nuevo ruedo de combates intergénero por la defensa de las respectivas libertades y de los distintos intereses en juego, batallas que algunas intentan librar reapropiándose de modos masculinos de ejercicio del poder, y otras, inventando o reinventando formas propias.

Ahora bien, respecto del amor heterosexual, la dinámica del poder plantea reveses adicionales. Como sucede en el plano económico, en el campo de las relaciones amorosas la explotación no siempre involucra la coerción o el abuso de forma consistente. Algunos enfoques sostienen, incluso, que a menudo beneficia a ambas partes, aunque una de éstas controle mucho mejor que la otra las ventajas diferenciales que mantienen en funcionamiento el sistema de explotación. Más aún, la mayoría de las veces ocurre con pleno consentimiento (Jónasdóttir, 2010). Retomando el pensamiento de las feministas radicales de los Estados Unidos, la antropóloga española Mari Luz Esteban también considera que una teoría del amor es de algún modo una teoría del poder y de la justicia, en tanto jerarquiza, ordena y excluye. El desafío, dice, bascula sobre un doble reconocimiento de naturaleza paradojal: "El amor es una trampa para las mujeres, un engaño. En esto coincide cualquier mujer que tenga un mínimo de sensibilidad social. Pero las dos dimensiones, el amor como lo sublime y el amor como engaño, no se afectan, no se invalidan entre sí, sino que se entienden como perfectamente compatibles" (Esteban, 2011: 53). Por su parte, Kristeva ya señalaba que, a pesar de los profundos cambios, el discurso romántico tradicional no desaparece (en Collin, 1991). Más bien pervive en coexistencia con múltiples estéticas de lo erótico, distintas inversiones psíquicas en torno del amor y la satisfacción del deseo sexual, y desiguales salidas de mujeres y varones al encuentro libidinal. El resultado de estas coexistencias es una suerte de archipiélago extendido y difuso de modos erráticos de encuentro, negociación y disfrute.

Visto de esta manera, mucho del optimismo acerca del éxito de las consignas emancipatorias de los años sesenta puede ponerse en cuestión. Los efectos negativos de la anticoncepción hormonal en la salud femenina, las presiones geopolíticas sobre la planificación familiar que hizo a las mujeres "responsables" de la sobrepoblación del planeta y las coerciones comerciales ejercidas por la industria farmacéutica para medicalizar el control de la natalidad, tensionan la apreciación unívocamente liberadora de la píldora (Felitti, 2012). Michel Bozon (2002), por su parte, es reticente a denominar como "revolución sexual" los cambios producidos en las conductas sexuales a partir de la segunda mitad del siglo XX. En su opinión, se trató más bien de un pasaje de la sexualidad construida por controles y disciplinas externas a una que reposa en normas internas. Más que una liberación, sostiene, ocurrió una internalización de las exigencias sociales, puesto que como producto social, la sexualidad nunca podría ser "natural" ni "liberada" totalmente. Claro está que estas advertencias tampoco invalidan el uso 
político del discurso liberal de propiedad privada del propio cuerpo. Tal como sostiene Judith Butler, políticamente es preciso sostener este estandarte, sin olvidar que "aunque luchemos por los derechos sobre nuestros propios cuerpos, los cuerpos por los que luchamos nunca son lo suficientemente nuestros. El cuerpo tiene una dimensión invariablemente pública. Constituido en la esfera pública como fenómeno social, mi cuerpo es y no es mío" (2006: 52).

Las reflexiones sobre los antagonismos emocionales y los desencuentros erótico-amorosos entre los géneros en el cambio de siglo no se agotan, claro está, en las referencias mencionadas hasta aquí. Por el contrario, se conectan y continúan en una vasta producción anterior y posterior, tanto proveniente de la filosofía como de la antropología y la sociología (Andreas-Salomé, (1998 [1910]); Badiou, 2011; Baudrillard, 1989; Bataille, 1988; Lorde, 2000, entre otros/as). Es conocido, al respecto, el amplio acuerdo en el campo de los estudios sociológicos e históricos de la sexualidad respecto de considerar a ésta como una construcción social. En términos de Michel Foucault (2008), la sexualidad es, ante todo, "un dispositivo histórico" que se constituye a partir de discursos que regulan prácticas, normalizan sentidos, instauran saberes y producen verdades. Implica entonces un arco extenso y complejo de rituales, lenguajes, fantasías, representaciones, símbolos, convenciones y procesos sociales y culturales que cambian con el tiempo, la geografía y los posicionamientos identitarios de quienes los encarnan. Estos discursos y prácticas circulan a su vez por diferentes campos - la política, las religiones, el saber médico, el psicológico, la escuela, los medios de comunicación, las industrias culturales, el mercado - resignificando sus relaciones recíprocas e incidiendo en ellos de diferentes modos (Weeks, 1993). En efecto, dichos campos establecen la norma en un sentido prescriptivo (lo que no se puede hacer) y, al mismo tiempo, imprimen una eficaz y sostenida regulación en torno de lo que debe hacerse, entre las sábanas y fuera de ellas.

Particularmente para el caso de las mujeres, estas indicaciones han moldeado históricamente las expectativas sociales alrededor de la figura ejemplificadora de la esposa, madre y ama de casa, delimitando con igual nitidez, pero con connotación inversa, los contornos de su negativo: la mujer que se rebela y cuestiona los mandatos. A su vez, junto con la producción de regulaciones ideológicas sobre la base de la variabilidad histórica del significado y las fronteras del pudor, la obscenidad o el erotismo, cada persona delinea, en sus múltiples recorridos subjetivos y sociales, diversas pautas para la rebeldía, nuevas normas para ir contra la norma, de perdurabilidad o contingencia histórica y contextual. En este sentido, a lo largo de diferentes momentos de la historia de Occidente, las mujeres fueron encarnando sus propios acontecimientos, experiencias, símbolos, estéticas, discursos y prácticas de "liberación": la joven que fuma, lleva cabello corto y mueve sus piernas al compás del Charleston en los "años locos"; el ama de casa que rechaza la "mística de la femineidad" de la segunda posguerra; las que queman su corpiños, se animan al "sexo prematrimonial" y cuestionan la maternidad y la heterosexualidad obligatorias como designios. Todas ellas son, en términos de representaciones colectivas, configuraciones sociohistóricas de "liberación sexual" asociada a las mujeres. 
Ahora bien, si en los años sesenta el "derecho al orgasmo femenino" comenzó a ocupar un lugar más visible en las superficies massmediáticas siempre dispuestas a convertir la sexualidad en mercancía, hoy la meta proclamada tanto por los formatos masivos orientados a las mujeres como por los arquetipos de la publicidad y el "bestsellerismo" de autoayuda, procura no limitarse al derecho de alcanzar el goce sino al de hacerlo reiterada y ostentosamente. Desde estos espacios se formula cada vez más el imperativo categórico a que las mujeres lleguen a ser multiorgásmicas e incluso "eyaculadoras" (www.entremujeres.clarin.com $2014 a$ y 2014b) y que puedan, para lograrlo, disponer de los diversos recursos que ofrece el mercado: juguetes sexuales, libros, revistas, películas, sitios web y talleres. La premisa es desarrollar una sexualidad lúdica, intensamente placentera y autotélica (Illouz, 2014: 81).

La interpelación que hace el conjunto de estos bienes y servicios orientados a la conquista de un mayor poder de atracción pone el acento en la necesidad de "aprender a ser sexuales" y de "invertir" tiempo, dinero y emociones para lograrlo. En esta línea, las "escuelas de seducción" para mujeres se revelan como espacios donde buscar, a cambio de una erogación monetaria, un saber cada vez más huidizo y multiforme, pero crucial. Si la escuela tradicional ha sido generalmente acusada, y con razonables motivos, de ser un lugar de ocultamiento y de estricto control de la sexualidad y del libre despliegue del cuerpo (Elizalde, 2014; Morgade, 2011; Elizalde, Felitti, Queirolo, 2009), estas otras “escuelas" se presentan como una alternativa formal para “aprender" aquello que ni allí, ni en el marco familiar fue enseñado. En Tentarte, por ejemplo, esta enseñanza se denomina "coaching sexológico" y tiene por objetivo "derribar las barreras que restringen nuestro crecimiento individual, fruto de la represión sexual, la mala información y la nula formación en materia sexual que se ve en nuestra sociedad" (www.coachingdeseducción. com.ar, 2014).

En cualquier caso, el presupuesto de que la sexualidad no es algo natural sino objeto de un saber experto encuentra eco en una y otra modalidad "formativa". En el campo de la educación sexual formal de la institucionalidad escolar, históricamente se consideró que los que sabían y debían enseñar sus contenidos era los profesionales de la salud y los docentes de biología. Esta concepción forjada en el siglo XIX, a partir de la creciente preeminencia del discurso científico en detrimento del religioso en estas materias, fue tributaria de un proceso de marcada medicalización de la sexualidad. Esto es, de "la definición de prácticas y estados sexuales como problemas de salud (y por ende diagnosticables) a resolver mediante la aplicación de técnicas y saberes expertos (tratamiento)"(Jones y Gogna, 2014: 141). Por su parte, en las escuelas de seducción también se aplica el presupuesto de la experticia. Se trata de las llamadas "profesionales del sexo", cuyos secretos y avezados conocimientos serán compartidos por las coach a cargo de los distintos talleres. Pero no de cualquier forma, sino de una que, prometen, será "divertida", "audaz", experencial y a la vez discreta, pues se hará entre mujeres "comunes" (casadas, solteras, amas de casa, estudiantes, etc.) y con el fin de ponerlo en práctica "en la intimidad del hogar" (www.pkescueladesexo.com.ar, 2014). 
Y, de este modo, "sorprender a la pareja", "regalarle un momento hot especial" o "mantener la pasión de un amor conquistado desde hace tiempo" (www. pkescueladesexo.com.ar, 2014).

De ahí que resulte interesante preguntarse si el motor que impulsa la participación de las mujeres en estas escuelas de sexo es la bandera de la libertad sexual y el propio placer, o la búsqueda de algún reaseguro en la prosecución del amor, donde el aprendizaje erótico está al servicio prioritario del mayor placer masculino. Un amor, paradojalmente, aún pensado y vivido por muchas de ellas en clave romántica, incluso - ¿o sobre todo? — cuando se lo acompaña con lencería de encaje, disfraz de colegiala y vibradores. Si hoy la igualdad sexual femenina disuelve la división arcaica entre las mujeres virtuosas y las corrompidas o degradadas, ¿cómo y con qué alcances se dirime esta disolución entre las mujeres?

\section{A SEDUCIR SE APRENDE:} ¿UN SABER AL ALCANCE DE TODAS?

"Si alguna vez te preguntaste qué quieren los hombres, cuánto dura el enamoramiento, si la rutina atenta contra la pasión, o qué decimos cuando no decimos... te invito a que juntos lo develemos!!!" (www.tentarte.com.ar, 2014).

Además del uso de imágenes de sensuales pinups de los años cincuenta, los flyers de promoción de los talleres para mujeres de la escuela Tentarte, donde se leen textos como el arriba citado, se valen de fotos de escenas míticas de erotismo del cine de Hollywood para ofrecer sus servicios. Marilyn Monroe sonriente con la pollera arremolinada por el viento que sale de la rejilla de ventilación del metro,
Ingrid Bergman ofreciéndole fuego a Humphrey Bogart en Casablanca o la voluptuosa Jessica Rabbit sonriendo con picardía. Lo sugerente es que la elección de este repertorio visual de feminidades arquetípicamente seductoras y presumiblemente irresistibles para los hombres, convive, sin mayores tensiones, con un discurso que garantiza el carácter automáticamente inclusivo de la invitación "a todas las mujeres" - las solas, las casadas, las que solo buscan divertirse-, así como a todos los cuerpos, todas las edades y todas las circunstancias sociales de clase y profesión. Esto es así porque, nos aseguran, "no es necesario ser una top model para desplegar toda tu sensualidad y erotismo. ¡Atrevéte a más!"

La invitación de la "escuela de sexo" $P K$ va en el mismo sentido: “ ¿Sos una mujer sola, con pareja, con ganas, joven, grande, mayor, gordita, flaca, dulce, seria...? Entonces te invito a pasar una tarde de domingo distinta [...] para que te sientas "como nueva'" (www.pkescueladesexo.com.ar, 2014). Sin embargo, esta dimensión inéditamente "democratizadora" de la seducción, en tanto proyecto individual disponible para el conjunto de las "mujeres comunes", no es en verdad de acceso indiscriminado. Para beneficiarse de ella es preciso reunir, al menos, dos condiciones que operan como petición de principios en ambas escuelas estudiadas. Una refiere a la voluntad personal - - leída en términos de esfuerzo, incentivo, responsabilidad, "garra" - que se requiere para volver a sentirse "como nueva". Argumento que también da por supuesto la aceptación de buen grado de la erogación económica que implica dicha travesía, infinitamente más barata que, por ejemplo, una cirugía estética. ${ }^{3}$ La segunda 3 El taller puede pagarse en efectivo o por el canje de un 
condición alude a la invocación de un atributo que actúa en reemplazo más o menos eufemístico de la falta de un cuerpo perfecto (que sí tendrían las insinuantes pin-ups y las divas de Hollywood). Se trata de "tener actitud"y "ponerle onda". Al respecto, los talleres de seducción prometen trabajar duro en pos de que las participantes logren sacar a relucir ambos atributos.

Mientras que el eslogan de una afamada escuela de seducción para hombres con sede en Buenos Aires dictamina que "un hombre no es completamente exitoso en su vida si no es exitoso con las mujeres", ponderado, según sus parámetros, por la cantidad de conquistas logradas (www.levantart. com.ar, 2014), las escuelas de seducción orientadas a mujeres se montan sobre otros argumentos. $\mathrm{Su}$ razón de ser responde al desgaste propio del paso del tiempo en una relación, la disminución de la pasión o el peso de la rutina, circunstancias ante las cuales se presupone que las mujeres "deben" actuar. Además, se agrega el argumento de buscar acrecentar la propia autoestima, habilitar la curiosidad por nuevas formas de experimentar y dar placer, reapropiarse y jugar con el erotismo como dimensión disponible para todas (y no sólo para las "profesionales" del sexo), y aspirar a "una vida sexual divertida y feliz" (www.pkescueladesexo.com.ar 2014).

Este plexo heterogéneo de motivos está presente, con matices, en el discurso de Tentarte

cupón de descuento adquirido en una de las numerosas páginas web de compras multi-rubro. Su precio equivale a una entrada al teatro o a un corte de pelo en un salón de prestigio. Este fue, de hecho, el modo de acceso de las autoras al "Taller intensivo de striptease y seducción" brindado por la responsable de Tentarte. El anuncio del cupón de descuento del sitio Letsbonus decía: "¡Sorprendé a tu pareja! Taller de seducción en Palermo." y en el de $P K$. Por poner un caso, en los talleres ofrecidos por $P K$ se da por sentado, por ejemplo, que las mujeres nunca están conformes o seguras con sus cuerpos, que temen perder al hombre que les gusta porque no son lo suficientemente "buenas en la cama", que no saben cómo seducirlo, cómo ocultar sus déficits de belleza o de exuberancia o —en menor medida - que están "en la búsqueda" o con nueva pareja y entonces quieren "explotar todas sus armas de seducción", o "ser más sexy de lo que ya son". Se trata, pues, de aprender qué se "debe" hacer para que el marido no se vaya con otra, para que la siga deseando o, en el caso de no tener una pareja, para conseguir una. Se presupone que ellas son responsables del "salvataje" si no quieren estar o quedarse solas e, incluso, responsables de su propia insatisfacción. Paola Kullock lo explica elocuentemente: "los hombres son malos amantes porque las mujeres les mentimos en la cama", remitiendo a la posibilidad femenina a fingir los orgasmos (Kullock, 2014). En respuesta a este tipo de "errores" femeninos, los talleres apuntan al despliegue de una "formación" que les permita a las alumnas aprender a seducir con la mirada, los movimientos del cuerpo o una postura sugerente. Pero sobre todo, a promover el acercamiento masculino y una vez que sucede, a conservar la conquista. No se trata tanto de desarrollar habilidades que puedan ponerse en práctica en, por ejemplo, un espacio virtual de citas, como de reconfigurar y reforzar el deseo heterosexual de la pareja que se tenga desde hace años, o de un nuevo pretendiente, en el terreno del encuentro personal y tangible. 
Por contraste, las escuelas de seducción para hombres - en la Argentina existen unas diez, casi todas en Buenos Aires - prima el mandato de la insistencia y la apuesta alta ("encarar como mínimo 20 mujeres por salida a un boliche"), así como la idea de la transmisión pública de una estima alta constante, inmune al fracaso o la decepción, que tendría como recompensa garantizada el despertar la atracción femenina. Despegado completamente de la matriz romántica, el éxito de este aprendizaje para varones es medido por la concreción del encuentro sexual, más que por el logro de un vínculo intersubjetivo cifrado en el código amoroso tradicional. De hecho, dos de las principales "escuelas" de este tipo, Seducción Secreta y LevantArt, ${ }^{4}$ emplean el denominado "método indirecto" o "de falsa indiferencia", basado en el uso de los llamados "negas". Esto es, producir frases descalificadoras "para bajar la autoestima de las chicas lindas" y lograr que presten atención al seductor ya que, afirman: "El mayor afrodisíaco para una mujer es decirle "No"” (www.seducciónsecreta.com.ar, 2014). Claro está que algunas de las técnicas promocionadas por estos espacios de entrenamiento en una "hipermasculinidad" basada en el reconocimiento social intragénero, el carácter sexy y la potencia sexual han generado fuertes controversias. ${ }^{5}$

4 Ambas son franquicias locales de una empresa de origen estadounidense.

5 El suizo Julien Blanc ha generado una polémica mundial por las modalidades que emplea en sus cursos. Para que las mujeres "rueguen por dormir contigo" o seducir a "una súper modelo europea en un día" (www.pimpingmygame. com, 2014) no duda en recomendar, por ejemplo, tomar de la cabeza a una mujer y empujarla a la entrepierna o tomarla por el cuello de manera violenta. Estas propuestas le valieron la calificación de "persona no grata" y la cancelación de sus
Aparentemente imperturbables ante estas búsquedas masculinas de una sexualidad acumulativa y desamorada, las escuelas de seducción para mujeres siguen firmes en la convicción de que todas quieren, finalmente, encontrar un varón con quien divertirse, gozar y acompañarse. $\mathrm{Y}$ asumen que eso no se logra si no es con esfuerzo, actitud y autoconfianza. Así, con el señuelo de convidar a que "te sientas y veas segura, femenina, sexy y seductora", la fundadora de $P K$ pide, como punto de partida para un verdadero "aprendizaje" en pos de los resultados prometidos, un ejercicio de sinceridad y autoexamen. Desde una foto a toda página de sí misma, vestida con lencería de encaje y accesorios de flores y perlas - ilustración de un afiche de promoción de uno de sus talleres-, la propia coach mira directamente al ojo de la cámara y pregunta: “¿no sabés caminar con tacos [tacones]?”, “ ¿sentís que no sos 'femenina'?", "en cuanto ves un hombre que te interesa ¿te cruzás de brazos y te ponés tímida?”, “¿no sabés 'manejar tu cuerpo’? ¿tenés mala postura?”, “¿estás deprimida?”, “¿entrás a un lugar y "no te mira nadie'?", "¿tu marido ya "no te ve'?”, “ ¿tu cuerpo cambió (engordaste o adelgazaste mucho) y "no te encontrás"?, ¿"no te gustás?" Ante tales preguntas, intenta inmediatamente calmar la posible angustia y exhorta: " $¡ v e n i ́$, vas a divertirte y a sacar lo mejor de vos!", al tiempo que asegura: "la seducción está compuesta por un $70 \%$ de actitud y un 30\% de belleza", y por ende "iTodas tenemos la capacidad de seducir, sin limitaciones ni condicionamientos!"

En su estudio sobre los cambios en los modos de vivir el amor a partir de la modernidad, Eva cursos en varios países del mundo (La Nación, 2014). 
Illouz (2012a) sostiene que en el desregulado mercado amoroso actual, la belleza ya no alcanza como criterio suficiente de elección de pareja. El polisémico pero "vendedor" atributo del "atractivo sexual" se ha convertido en el nuevo capital estratégico para sobrevivir en dicha "selva". Hoy es, en efecto, un criterio altamente legitimado y consciente para los sujetos, al punto que resulta tan importante como la compatibilidad psicológica y la intimidad emocional. En todo caso, la belleza que antes era pertinente como manifestación del carácter moral, está ahora atravesada por las lógicas del consumo, pero también por la diseminación del discurso de derechos sobre la igualdad de goce erótico para varones y mujeres, y la multiplicidad de formas de disfrutar el cuerpo. De allí que su posible trascendencia se plasma actualmente en la utopía del cuerpo individual (Vigarello, 2005) y en el culto a la belleza y al buen estado físico. Exigencias que también incluyen a los varones (Bordo, 2000) dada la importancia que adquiere el ser capaz de despertar deseo erótico en otras personas.

En un mundo en el que impera la libertad de elección de pareja y rebosan las oportunidades para concretar encuentros sexuales, el cortejo - en tanto ralentización de la presencia y juego incesante del desvío simbólico que impulsa la libido (Bataille, 1988) - , parece volverse obsoleto. Por contraposición, contar con "competencias sexuales", "tener actitud" y desbordar sex appeal se tornan atributos de suma relevancia para "no quedar fuera" (Giddens, 1998; Illouz, 2012a). De hecho, hay todo un mercado dispuesto a ofrecer los conocimientos "necesarios" para su adquisición, como atestiguan las "escuelas de artes eróticas" estudiadas, inscritas en esta vastísima industria cultural construida en su entorno. Como sostiene Illouz, "la cultura del consumo coloca el deseo en el centro mismo de la subjetividad, y la sexualidad se transforma en una suerte de metáfora generalizada del deseo" (2012: 63).

Esta reformulación o desplazamiento de la centralidad de la belleza física femenina como inexorable "parteaguas" del éxito o el fracaso en el logro de la atracción sexual, integra sin disimulo el discurso de estos espacios de "enseñanza erótica" para mujeres. Por caso, en el flyer de promoción del "Taller de bailes sexies" de la escuela $P K$ se afirma: "Si sos alta, baja, gordita, flaca, pechugona o chata como una tabla, excelente bailarina o pata dura, mayor de cuarenta o menor, ya seas preciosa o no respondas a los cánones actuales de belleza... ¡vos podés! [...] Porque hacer un baile sensual —nos asegura - es una cuestión de actitud y de ganas" (www.pkescueladesexo.com.ar, 2014).

En esta línea, ser y tener actitud sexy deviene una "necesidad", un requisito para pertenecer, del mismo modo que cotizan alto tener un saber experto y una copiosa experiencia sexual, aunque - no hay que olvidarlo - la apuesta se juegue siempre en un escenario - el erótico-amoroso- que no provee garantías (Badiou, 2011). De hecho, en las culturas utilitarias, en las que el sujeto debe aspirar al placer y esforzarse por ello, el sufrimiento no resulta útil, sino un sentimiento que destruye los cimientos mismos del yo (Illouz, 2012b). Los nuevos mandamientos del reino del individuo se conforman por el "derecho-deber ser" a la autorrealización personal, la libre elección, el placer y la seguridad (Bajoit, 2012). De allí que tanto en las narrativas 
terapéuticas como en las pedagógicas vinculadas con la sexualidad - pero también, y como reverso, en la experiencia subjetiva de muchos/as de sus destinatarios/as - se advierte una coexistencia tensa y perturbadora entre la lógica del mercado, las nuevas imposiciones culturales asociadas al sex appeal y el discurso de derechos; entre el imperio de un individualismo a ultranza y el reclamo del reconocimiento del propio sufrimiento, junto con la exigencia pública de su remedio (Illouz, 2007).

En palabras de Robert Muchembled: "Mientras que en apariencia el individualismo triunfa, las leyes del mercado económico y la tiranía del orgasmo condenan [al sujeto] a tornarse en un atleta del logro personal, obligado constantemente a demostrarle a los demás que puede hacer algo mejor" (2008: 387). En efecto, "trabajar" (en) una relación y "trabajar" en uno/a mismo/a se ha vuelto un imperativo (Kipnis, 2008). El conjunto de estas tensiones instalan al sujeto - en nuestro caso, a las mujeres - en un combate interno entre deseos e impulsos en conflicto, que no se apacigua necesariamente en la concreción de sus fantasías o conquistas sexuales, sino que con frecuencia relanza cíclicamente la angustia respecto de la propia integridad. "Tratamos de sostener [todos estos deseos] al mismo tiempo, y la pregunta es si eso es posible", reflexiona Illouz. "De cierto modo hemos perdido la capacidad de jerarquizar quiénes somos y qué queremos de la otra persona" (2012b).

Lo cierto es que, en esta encrucijada, las mujeres parecen avanzar más bien a tientas.

\section{DEVENIR SEX SYMBOL}

Si bien los talleres brindados por las dos escuelas de seducción para mujeres parecen confluir en el mismo objetivo - el de promover la autoestima femenina con base en la (estratégica) confianza en el potencial erotizante de todas las asistentes- los modos en que estos argumentos se patentizan en los encuentros cara a cara con las participantes presentan sugerentes especificidades en uno y en otro caso.

Formada en relaciones públicas, Celine Stajcer, la responsable de Tentarte, terminó dedicándose al "coaching de seducción” y al desarrollo de numerosos servicios interconectados por diversos motivos personales - afectivos, de reinvención laboral—así como por la convicción de que hacían falta lugares donde recibir información hot y, al mismo tiempo, divertirse. Sus talleres, que la tienen como única profesora a cargo del grupo, se dictan habitualmente en "Te Mataré Ramírez", un restaurante de comida afrodisíaca ubicado en el barrio porteño de Palermo, un enclave turístico reconocido por su impronta de diseño y moda de vanguardia y su circuito de ofertas gastronómicas. Con hora de inicio a las tres de la tarde, cuando el local está aún cerrado al público, los dos encuentros relevados para este análisis tuvieron lugar los días sábados e incluían una parte "teórica" y una "práctica", previa copa de champagne que Celine convidaba a las asistentes a modo de bienvenida. Vestida con un catsuit de lycra negra con escote pronunciado, cabello largo rubio, ojos verdes y un cuerpo delgado y con curvas, en el primer encuentro repitió varias veces que todas podíamos ser sexies. Y aseveró que sólo se requería "garra y actitud". La sección teórica del taller comprendía una exposición suya, de media hora, y la sección práctica, la enseñanza y ejercitación grupal de una coreografía de striptease. Para esto último, 
se indicaba llevar pantalones de lycra ajustados, camiseta sin mangas ceñida al cuerpo, tacos altos y una camisa y corbata masculinas.

En uno de los talleres, la exposición teórica versó sobre las “diosas sensuales de todos los tiempos". De repente, la figura de la diosa sagrada, propia de las tradiciones ancestrales y actualmente devenida nuevo tópos del pensamiento y el lenguaje femeninos entre ciertos movimientos provenientes del giro espiritual y la New Age (Simonis, 2012), adquirió, aquí, un significado expresamente sexual. En el taller de Tentarte, la información sobre estas nuevas diosas incluyó la proyección en pantalla de un arco diverso de imágenes de mujeres, desde geishas hasta bailarinas famosas como Mata Hari, pasando por modelos de mujeres vamps y kunoichis, pin-ups y divas de Hollywood, hasta concluir con el ícono erótico del cine nacional argentino, Isabel "La Coca" Sarli. En el segundo taller, la sección teórica consistió en una charla instructiva sobre las poses, los gestos y los movimientos que integrarían el "lenguaje de la seducción", los cuales — se nos dijo- serían inequívocamente decodificados por los varones como signos del interés sexual femenino hacia ellos. A modo de "tips infalibles" se mencionó, por ejemplo, jugar con un mechón de pelo y enroscarlo entre los dedos, morderse levemente los labios, fijar la mirada en los ojos del varón que nos atrae, correr distraídamente un bretel para dejar al descubierto un hombro, o balancear el pie para jugar a sacarse y ponerse un zapato de taco, movimiento que - aseguró la coach — permitiría insinuar con sutileza la disposición a desnudarse frente al varón y/o avanzar hacia la concreción de un encuentro sexual.
En la parte práctica, se nos invitó a ponernos de pie, descalzas primero y con tacos altos después (sugerencia que varias no acataron), para así empezar a imitar los pasos de striptease que la coach mostraba, que fueron creciendo en complejidad a medida que la coreografía se completaba. La idea era embarcarse en el aprendizaje intensivo de pasos codificados para sacarse la ropa con sensualidad delante de un imaginario caballero, hasta quedarse (supuestamente) en ropa interior o con lo mínimo. Todo se hacía al son de canciones "cachondas" para que el varón imaginado frente a cada una fuera "calentándose hasta no poder más" (Notas de campo, 2013a). De este modo, caminar acentuando exageradamente las caderas, mirar de reojo, acercarse gateando hasta él para retroceder en el momento exacto en que ya era posible ser alcanzada, ${ }^{6}$ bajarse de un tirón la camisa hasta los hombros, tocarse con alevosía el cuerpo o pasar la corbata por un muslo y luego alzar la pierna sobre el asiento de una silla, fueron parte de los calculados pasos que se proponían aprender en una acelerada y cansadora sesión de baile. Entre risas y comentarios graciosos, pero también con mucha concentración y riguroso entrenamiento por parte de las asistentes, ambos talleres de Tentarte concluyeron con un gran ensayo general y sin interrupciones del baile "más hot que se puedan imaginar". "Vamos, vamos, todas podemos sacar esa diosa explosiva que llevamos dentro", fue una arenga frecuente de la coach durante todo el ensayo.

Por su parte, el taller de $P K$ se realizó en un salón de fiestas de Villa Urquiza, un barrio

6 El exhorto aquí fue: "si quiere tocar, que pague" (Notas de campo, 2013a). 
con un perfil habitacional de clase media, sin atractivo turístico particular. En él participaron unas 25 mujeres, de entre 29 y 70 años. También incluyó un momento de charla por parte de la coach, Paola Kullock, quien, vestida con un short, remera y zapatillas, pero prolijamente maquillada, alentó en todo momento un fluido intercambio de opiniones con las asistentes, usando para ello mucho humor e incluso recursos del stand up. El tono de las conversaciones fue ameno y franco. Así, por ejemplo, se conversó sobre "los arquetipos masculinos a la hora de coger [tener sexo]": "los que no acaban nunca", "los que preguntan todo el tiempo si te gusta", "los que quieren que grites o tengas muchos orgasmos", "los que se auto elogian el tamaño" (Notas de campo, 2013b). En esta primera parte también se proveyó de consejos para sentirse $\mathrm{y}$ verse sexy, como mirarse desnuda frente al espejo, con tacos altos puestos, maquillada y peinada "para descubrir nuestras zonas más hermosas", usar la vajilla de lujo que solo guardamos para las visitas, tirar las bombachas (bragas) viejas, no usar corpiños color piel, aprender a hacer una fellatio "de exhibición" o a simular que se traga el semen sin hacerlo.

"Entrecerrar los dientes de modo de que parezca que es tanto que se derrama, así no queda como que lo rechazás y el hombre siente que eyaculó mucho" (Notas de campo, 2013b), fue el consejo de la coach a las asistentes, quien aseguró que lo aprendió viendo películas pornográficas y a partir de su propia experiencia. Si bien esto era un truco, la coach resaltó los riesgos de algunas otras "mentiras piadosas" que solo satisfacen el goce masculino e ironizó sobre "la moda de las mujeres multiorgásmicas". A viva voz preguntó a las asistentes: “¿hay multiorgásmicas en este grupo?” y generó un debate sobre cuántos orgasmos eran suficientes para entrar en esa categoría. Una chica pelirroja, corpulenta, con pechos grandes, aseguró que ella llegaba a cinco. Otra mujer, menuda, de unos cincuenta años, redobló la apuesta y gritó “¡nueve!”, aunque aclaró que solo le sucedió una vez. El resto de las concurrentes, la aplaudió entre risas y festejos (Notas de campo, 2013b).

La parte práctica del taller consistió en un conjunto de ejercicios con el cuerpo dirigidos por una bailarina. Como testimonio de su autorrealización contó que de niña, siendo "gordita" y luego con $120 \mathrm{~cm}$ de contorno de busto, su cuerpo no respondía al modelo de bailarina delgada ni le quedaban bien los trajes de baile, pero que aún así siguió adelante y finalmente logró destacarse como una buena profesional. Con esto procuró adelantarse a los lamentos esgrimidos por algunas asistentes, que dijeron que no sabían bailar ni moverse con gracia, que tenían vergüenza o que ningún hombre las invitaba a bailar. El entrenamiento se inició con un pedido: que todas las asistentes, recostadas en el piso con los ojos cerrados, pudieran reconocer y sentir las diferentes partes del cuerpo hasta ubicar mentalmente la pelvis y advertir allí su fuerza y poder energético para "estar centradas". Una vez de pie, y al son de distintos ritmos, se propuso caminar por el salón, moviéndose libremente. Luego se preguntó qué ritmo había resultado más placentero para cada una, para seguidamente explicar que cada ritmo representaba un elemento de la naturaleza (agua, aire, fuego y tierra) y, por lo tanto, una 
energía particular. Con esta información cada mujer podría reconocer su propia energía individual movilizada en una situación social de baile, así como la del varón que se quisiera seducir, por cuanto el erotismo se asentaría en el intercambio fluido de energías que se atraen. Por último, se ensayaron algunos movimientos para acentuar la carga erótica del cuerpo, con foco en las caderas ("centro de la sensualidad") y la pelvis ("eje de la sexualidad"). Se aconsejó, finalmente, seguir ejercitando estos movimientos en las casas, en lo posible con zapatos de tacos altos puestos.

En síntesis, más que un espacio de cuestionamiento o desnaturalización de mandatos de género, los talleres de ambas escuelas funcionan como respuestas mercantilizadas a una creciente pero aún difusa demanda de "aprendizaje" femenino sobre sensualidad y erotismo, que a su vez ayudan a fomentar. Sin embargo, al invocar dichos mandatos en una conversación distendida entre mujeres, generar debate y movilizar el cuerpo a partir de ello, pueden ir mucho más allá de sus objetivos iniciales. Las mujeres aprenden de sí mismas y de las otras compañeras, hablan de sexo en público, verbalizan el deseo, la fantasía y/o la angustia de la decepción - muchas por primera vez-, y se reconocen solidariamente entre sí en distintas situaciones de sus trayectorias vitales, eróticas, afectivas y socio-sexuales. De allí que, junto con las admoniciones sobre la necesidad de revitalizarse sexualmente para evitar la huida del varón, las propuestas de estos talleres también combinan propósitos que, sin usar este término tan caro al feminismo, tienen efectos "empoderadores" para ellas.
"Yo nunca imaginé que podría volver a sentirme sexy, como cuando tenía 20 años", dijo Graciela, de 46, casada desde hacía 23, que había venido desde Lanús, una localidad alejada de la capital, a tomar el taller de Tentarte. "Ya no es lo mismo, tengo otro cuerpo, estoy gorda, con todo caído, pero sigo teniendo ganas de jugar con mi marido. Y de acá siento que me llevo cosas para animarme a hacerlo." Al final del taller, coreografía de striptease mediante, Graciela encargó un traje XL de diabla, con tridente y cola de raso rojo (Notas de campo, 2013a).

Como contraparte a estas ganancias, una cuota de frustración también se asoma. No se trata solamente de que el cuerpo no quepa en el corset o no se llegue a la elongación que el baile exige. Las dos profesoras, de los dos cursos, cuando se cuentan a sí mismas se presentan como mujeres que no siempre han tenido suerte con los hombres, o que han sido engañadas, dejadas. De hecho, Kullock sentenció: "ser buena amante no significa que no te van a dejar" (nota de campo 2013b). Y si bien esto se sabe, pareciera regir un pacto entre las asistentes. Los cursos funcionan también como un lugar de catarsis, en ese caminar desprejuiciado, suelto, moviendo las caderas, con la mirada en alto, aunque los cuerpos se choquen y en algún lugar se haga el ridículo. Mujeres entre mujeres para aprender (nuevamente) a ¿ser? mujeres, o más bien, "la mujer" que el sistema sexo genérico heterosexual desea, impone, demanda. Varias de las asistentes al taller de $P K$ dicen que fueron esposas y se dedicaron largamente a criar los hijos/as pero que ahora quieren "ser mujeres". Sexies. 
“PONÉLE PORNO A TU VIDA

Y VESTITE DE CONEJITA!"

Como parte de un mercado que Anthony Giddens no dudó en calificar como de "sexo de emoción baja y alta intensidad" (1998: 73) pero a la vez, de potencial radicalización de la dimensión democrática de la sexualidad, el circuito de "enseñanza" sobre las "artes eróticas" que construyen estas "escuelas de sexo" para mujeres se completa con la venta de una variedad de productos y servicios, en pos de "hacer más divertida y picante tu vida sexual" (www.pkescueladesexo.com.ar, 2014). Tentarte desarrolla el rubro de la "dulcería erótica" (pastelería con motivos sexuales) y una línea de "regalería hot" que incluye kits con variedad de objetos ("lubricantes saborizados", "perfumes afrodisíacos con feromonas", "dados Sutra", "chupetines grandes", "bombones hot"). $P K$, en cambio, se especializa en las "sex parties", 7 que abarcan desde charlas-shows sobre juegos eróticos y juguetes sexuales en despedidas de solteras, celebración de divorcios, cumpleaños y encuentros sociales de mujeres, hasta el asesoramiento y la realización de books de fotos sensuales, el dictado de talleres para parejas (sobre "juegos previos", "masajes hot", "para iniciarse en el swinger”, etc.) y clases especiales exclusivas para mujeres ("estilos, técnicas y secretos de masturbación femenina", "taller de bailes sexies"). Asimismo, ofrece talleres de "Bondage y Shibari" a cargo de otro colaborador, Master Ciro, aprovechando la veta comercial que abrió la popularización de la estética BDSM (Bondage, Disciplina, Sadomasoquismo) a partir del boom

7 Tentarte también las organiza pero con menor repercusión mediática. editorial de las novelas de Erika Leonard James, la trilogía que inaugura Las 50 sombras de Grey, en las que el protagonista se inicia en el sadomasoquismo. Completa su oferta una variedad de clases "sólo para hombres", en las que se enseñan "técnicas de sexualidad y erotismo" y "cómo ser un amante inolvidable", entre otras propuestas. Finalmente, Kullock trabaja también como animadora en cruceros para solos y solas, organizando actividades lúdicas que faciliten y promuevan los encuentros, y organiza visitas grupales a espacios de encuentro y esparcimiento sexual, como locales en donde practicar "swingerismo" o campamentos nudistas.

De este modo, los públicos se renuevan pero también se desplazan constantemente de una oferta de "enseñanza" o "entrenamiento" sexual a la otra. Incluso se llega así a conformar grupos "fidelizados" de consumidoras/alumnas, agrupadas bajo formas eufemísticas de "graduadas" de dichas "formaciones" y vueltas a convocar en nuevas opciones de consumo. Entre ellas, las "fiestas de egresadas" donde se entregan diplomas, se realizan sorteos de repostería erótica, lencería hot, "becas" para otros cursos y cenas. En la fiesta de fin de año que organiza $P K$ se invita a las mujeres y a los varones que tomaron allí diferentes cursos durante el año, para que se conozcan aunque también pueden ir personas "externas" a la escuela, potenciando las chances de que se conviertan en futuros/as clientes/as. Para esta época de fin de año ${ }^{8} P K$ ofrece también la producción de un libro de fotos eróticas. La idea es que cada mujer se haga este regalo a sí misma o a quien desee. En diálogo personal con una de las asistentes al taller, una mujer contó que las 12 fotos que se sacó desnuda y en 8 Los cursos se tomaron a finales de 2013. 
posiciones sexies las tiene guardadas en un sobre. Para ella no fue el resultado sino el proceso lo que le valió la pena, el "cómo me sentí liberada", ya sea por el hecho mismo de decidirse a hacerlo, de estar casi desnuda frente a un fotógrafo y otro asistente varón, y/o de estar cambiándose la bombacha delante de otras personas. 'Nunca había pensado que podría hacerlo" (Notas de campo, 2013b). Esta propuesta tiene un costo elevado, si se compara con las otras, pero aún así es bastante solicitada. Jugar a ser modelo de revista erótica o porno forma parte de la fantasía de muchas mujeres. De hecho, algunas de las imágenes que las mujeres utilizan para presentarse en los sitios de encuentro corresponden a este tipo de producciones profesionales.

Otra fantasía femenina que se legitima, o al menos que se verbaliza en público, es la del sadomasoquismo. En el taller de $P K$, la participante más joven, de 20 años, contó que estaba allí porque "me gusta pegar y mi novio es otro enfermo como yo. Nos encanta." Si bien la instructora le respondió que había otros talleres específicos "para eso", la cuestión quedó instalada (Notas de campo, 2013b). "Porno para mamás" es la calificación despectiva que se ha usado para calificar al universo de lecturas y lectoras que crecieron exponencialmente con la historia de Mr. Grey, convertida en punta del iceberg de una saga de literatura erótica femenina mucho más amplia. Con más de 70 millones de ejemplares vendidos y una recaudación millonaria de su versión cinematográfica estrenada mundialmente en $2015,{ }^{9}$ el vasto mercado de productos "porno soft" activado en su entorno ha puesto al bondage

9 En la Argentina, el estreno fue el 14 de febrero, día de "San Valentín" o "de los enamorados". y el sadomasoquismo en la cima del repertorio lúdico-sexual para las "mujeres comunes".

Ocupándose de este fenómeno, Eva Illouz criticó enérgicamente la atribución peyorativa respecto del lugar de las mujeres (en tanto "mamis"), ante los convites de un relato que las conecta con fantasías sobre el amor y la sexualidad. Para ella, estas descalificaciones "ignoran la compleja estructura cultural de la sexualidad de las mujeres, que no sólo responde a propósitos de placer, libertad y poder, sino también a proyectos de identidad y al manejo de relaciones cercanas e íntimas" (2014: 48-49). En nuestras observaciones de campo notamos que quienes buscan aprender las técnicas del bondage, o sienten curiosidad acerca de ellas, explican su interés como una respuesta a esta oferta literaria y sus productos asociados (antifaces, látigos, vendas, esposas). ${ }^{10}$ Es decir, gran parte de las mujeres que toman cursos exclusivos sobre esta modalidad no parecen desafiar de manera consciente o al menos manifiesta la práctica sexual "convencional". Beatriz Preciado (2011) propone en su manifiesto contrasexual, justamente, deconstruir la naturalización de las prácticas sexuales y del sistema de género en su matriz hegemónica. En las sociedades modernas, dice esta autora, el sexo aparece como una tecnología de dominación heterosexual en la que impera una reducción de la superficie erótica a los órganos sexuales reproductivos. Por contraste, en el repertorio de las prácticas contrasexuales que menciona, la utilización de dildos, la erotización

10 La "Caja de Grey" ofrece diferentes productos, todos en color negro o plateado, con el logo de 50 sombras. En el sitio web oficial de promoción cada producto se muestra en detalle junto con la transcripción del fragmento del libro en donde se lo utiliza (http://www.lacajadegrey.com) 
del ano y el sadomasoquismo - siempre que sea resultado de un acuerdo o contrato-, entre otras, van en el sentido desnaturalizador propuesto.

Las mujeres que buscan en los sex shops porteños estos productos o que consultan por estas prácticas en las escuelas de seducción, o conversan entre amigas sobre ellos, no parecen, en cambio, estar guiadas por estas premisas de radicalización. Esto no significa que solo acaten la cuota de prescripción y reproducción de mandatos que implican estas propuestas de mercado; despliegan también libertad y márgenes de acción, en tanto sus consumos eróticos se actualizan en modos situados de reapropiación y empleo (Curtis, 2004).

Para la mayoría de las participantes de los talleres aquí estudiados, la accesibilidad a un mundo de movimientos, técnicas, prendas y fetiches íntimos - y a su concomitante promesa de goce sexual-, en apariencia históricamente reservado a trabajadoras sexuales, modelos de cuerpos esculturales, divas de la televisión o veinteañeras en plena experimentación, instala una doble expectativa. Por un lado, la de participar de un escenario que roza (superficialmente) lo pornográfico, o lo altamente sexualizado, como valor en alza, pues permitiría ser o sentirse "sexy". Por el otro, la de practicarlo en la intimidad de las formas socialmente establecidas de relación: pareja, noviazgo, matrimonio. De hecho, la coach de Tentarte se esmera en un discurso apaciguador de conciencias: aclara que es una mujer casada y con hijos. Y recomienda nunca hacer un striptease o estrenar una lencería erótica en la primera cita, porque eso puede dar una mala impresión y disminuir las posibilidades de un segundo encuentro.
Lo cierto es que las propuestas de talleres, prácticas y productos eróticos para "mujeres comunes" se multiplican, generan entusiasmo entre las participantes y van dando forma a la idea de que tomar un curso de seducción abre las puertas a todo un universo, potencialmente infinito, de experiencias nuevas o inexploradas asociadas con el disfrute sexual y la búsqueda de pareja. Ambas "escuelas", además, ofrecen a sus "alumnas" la posibilidad de adquirir lencería y disfraces eróticos o, como prefieren llamarlos las coordinadoras, “trajes de fantasía íntima”. Ligas, encajes con moños, plumas, lazos para anudar al varón espectador, telas superpuestas para demorar la desnudez; disfraces eróticos "clásicos" (de "mucama", "enfermera", "diablita", "chica Playboy", "colegiala") y otros de temática más indefinida ("femme fatale", "pinup"), baby-dolls con pompones y transparencias, corsets, vinchas para el pelo con orejas de gato o conejo, tridentes y finos látigos forrados en raso... Un sinfín de prendas leves y adminículos diminutos se despliegan sobre mesas al final de los talleres de seducción de Tentarte, con las alumnas arremolinadas en su entorno, mientras la coach resalta en voz alta los detalles de cada prenda, explica cómo o dónde van puestas, contextualiza distintos usos y conveniencias. "Ésta es ideal para reconquistarlo", "con ésta tienen garantizado una noche de alto voltaje", "ésta resalta las lolas y disimula más las caderas". Junto a ello, relata casos concretos de estreno y resultados: "el otro día una alumna se llevó este modelo y me mandó un mail diciendo que nunca en su vida se había sentido tan sexy delante de su marido", "otra me dijo que el pibe se volvió loco cuando la vio entrar con 
este corset, y ella estaba en las nubes", "tuve una alumna gordita que se llevó este traje de diablita y estaba fascinada: viene hasta el talle XXL. ¡Hay para todas!" (Notas de campo 2013a). Como refuerzo está la propia experiencia de la coach en el empleo de la lencería y los disfraces eróticos que muestra en la reunión: “yo, chicas, tengo este mismo en casa, de enfermera, y con mi novio anterior lo usaba cada vez que él venía cansado y entonces me lo ponía y le decía que le iba a dar una sesión de cuidados intensivos" (Notas de campo, 2013a).

Como señalan algunas investigaciones feministas sobre reuniones privadas de venta de lencería y juguetes sexuales en Europa y los Estados Unidos (French y McCaughey, 2001; Storr, 2002 y 2003; Workman, 1996), los showrooms de productos sexuales para y entre mujeres construyen una "fraternidad femenina" u homosocialidad para nada despreciable, pero con evidentes límites. Por un lado, estos eventos habilitan la experimentación y el juego, así como el intercambio y la discusión sobre sexualidad, usos del cuerpo, concepciones del placer y transgresión de tabúes sociales entre las participantes en un marco de confianza y a resguardo de miradas censoras. Por el otro, y en simultáneo, constituyen zonas de refuerzo del intrincado pacto entre capitalismo y patriarcado, en el que las diferencias de clase, los capitales de la distinción cultural y los mandatos heteronormativos ponen en tensión los alcances empoderadores de estas experiencias.

El caso de la lencería es paradigmático. Lejos está de ser "necesaria" para mantener el calor del cuerpo, no es visible en público y en general no se piensa en ella salvo que haya una visita al médico o un encuentro sexual posible. De ahí que su valor es alto no por lo que hace sino por lo que significa. En tanto innecesaria, es, en términos de Bourdieu, un accesorio que opera como un signo de distinción (Storr, 2003). Como mencionamos, uno de los consejos de la coach de $P K$ durante el taller fue tirar toda la ropa interior color piel. En su lugar, aconsejó usar corpiños y tangas colaless coloridas (Notas de campo, 2013a), recomendación que también hace la "gurú" de la autoayuda, Pilar Sordo, en su ensayo besteller Lecciones de seducción (2013). En todo caso, las exigencias respecto a qué ponerse como ropa íntima ponen en discusión, una vez más, los paradigmas de la liberación. De hecho, una de las marcas globalmente más famosas como es Victoria Secret rememora la época victoriana y tiene al corset como prenda emblema. El corset, el corpiño, ¿sujeta o libera sexualmente a las mujeres? Ponerse los pantalones en los años cincuenta, usar minifaldas y quemar los corpiños en los sesenta, ¿fueron la preparación del regreso de los encajes? En este sentido, como indica Workman (1996) es preciso contextualizar el artefacto del que hablamos y preguntarnos por el lugar que tiene esa feminidad sexualizada que puede mostrarse puertas adentro, de noche, mientras se lucha por la igualdad en el espacio público con otras armas. Misma interrogación puede hacerse con el vibrador, que hoy es un símbolo de autosatisfacción femenina pero que tuvo un origen a fines del siglo XIX menos libertario, en tanto tratamiento para la histeria y adminículo que facilitaba la cura (masturbación) por parte de los médicos (Maines, 2012). 


\section{CONCLUSIONES}

En este trabajo nos propusimos analizar parte de los vínculos que se establecen entre mercado, deseo y sexualidad en un contexto y tiempo históricos en el que las relaciones erótico-afectivas parecen signar crecientemente su lógica de configuración en una doble y contradictoria clave. Por un lado, la asociada a la extrema visibilidad e inmediatez que imprimen las nuevas tecnologías de comunicación, que vuelven prácticamente obsoleta la idea de cortejo y, por lo tanto, la del proceso de seducción como su recurso privilegiado. Y por el otro, la vinculada a las demandas de derecho al goce e igualdad sexual entre los géneros, resultado de las conquistas feministas de la segunda mitad del siglo XX en adelante. $\mathrm{O}$, cuanto menos, de los combates sociales contra el discurso del amor romántico, cuyos presupuestos de seducción instalan a las mujeres en la exigencia de un desempeño erótico acorde a una moral sexual intachable al servicio del hombre.

En este marco es que nos preguntamos por las condiciones actuales de producción del deseo y por los modos en que las "mujeres comunes" se implican en estos procesos. Así, mediante el análisis de las propuestas comunicacionales, los saberes y los productos ofrecidos por los talleres de seducción relevados para este análisis, procuramos señalar la interconexión de dos dimensiones decisivas. Por un lado, el carácter socialmente construido del deseo, aunque desigualmente disponible para varones y para mujeres en términos de atribución simbólica y alcance político para unos y otras. Y, por el otro, su estatuto inestable y conflictivo en tanto plexo de tensiones impuestas simultáneamente por el mercado, el discurso de derechos y la propia experiencia social y biográfica de los sujetos en relación con sus cuerpos, identidades y prácticas sexogenéricas.

De allí, pues, que el consumo de estos talleres por parte de cientos de mujeres no pueda leerse como resultado exclusivo de un narcisismo irresuelto, ni como evidencia indubitable de su sujeción respecto del dominio patriarcal y androcéntrico, entendido como poder sin fisuras. Cabe, más bien, reconocer cierta conexión entre estos cursos (y la vasta oferta de productos generada en su torno) y la promesa sexual imaginada en los años sesenta y setenta del siglo pasado. De alguna forma, estas "escuelas de artes eróticas" recuperan de aquella experiencia la aspiración democratizadora de la liberación sexual femenina puesta en circulación desde entonces. Al mismo tiempo, se instalan, en clave mercantil y con impronta pedagógica, en el espacio vacío que propicia el tajante rechazo de gran parte del feminismo a la matriz ideológica del amor romántico. Rechazo que deja a muchas mujeres sin recursos ni argumentos para negociar sus propios sentidos sobre el amor, el erotismo y la ilusión romántica, o directamente las ubica parafraseando a Stuart Hall (1984) — del lado de las "tontas culturales" (1984: 99) al enfrentarlas con sus elecciones, a priori concebidas como "erradas", "autodegradantes" o cómplices de la violencia machista y del patriarcado.

El viejo y nunca resuelto debate sobre "las guerras del sexo" entre quienes postulan la prostitución como un trabajo y quienes la denuncian como una forma más de explotación, encuentra en este contexto de mercantilización del 
deseo, los cuerpos y la sexualidad, nuevas aristas. Frente a la estridente denuncia de las feministas sobre la cosificación del cuerpo femenino y el encorsetamiento de los modelos de belleza, cada vez más mujeres se realizan intervenciones estéticas que responden a esos cánones, poniendo en jaque los alcances de ciertas consignas de autonomía. Ante esto, como polémica y provocación, cabría preguntarse por qué el ser dueña del propio cuerpo parece limitarse al derecho a practicarse un aborto o a vivir una sexualidad sin tope alguno, impactando en la posible legitimidad de otras decisiones y deseos, como el de resguardar la virginidad, integrar clubes de lectura de novelas de tintes sadomasoquistas, consumir pornografía, usar trajes de fantasía erótica o asistir a estas "escuelas" para aprender a moverse como una "profesional del sexo". Si, en vez de ello, complejizamos el planteo y asumimos que estas prácticas efectivamente satisfacen la consigna de ser dueñas de los propios cuerpos pero que, a la vez, también resuenan de maneras contradictorias y todavía inexploradas en las relaciones de género, se abren otros interrogantes y emergen nuevos retos. En este contexto, ¿es acaso posible pensar que las mujeres exigen igualdad en el espacio público pero desean la dominación masculina en la intimidad? (Snyder, 2008).

Entre la promesa de "empoderamiento personal" basado en ideas de autonomía corporal y libertad sexual, por un lado, y la invitación a convertirse en una "perra" con "formación profesional" en el arte de atraer a los varones, conseguir muchas citas y mantener una frecuencia alta de relaciones sexuales multiorgásmicas — sin temor a emplear para ello una variedad de juguetes eróticos, disfraces y lencería hot-, por el otro, estas nuevas formas de "pedagogía sexual" instalan una incomodidad de primer orden en el corazón de ciertos feminismos. Simultáneamente, representan un impulso - y también un límite — de nuevo signo en la experiencia de miles de mujeres que han sido socializadas en el discurso o en los legados de la "liberación" de su propio Eros como parte de la ansiada revolución sexual centrada en ellas. Por eso vuelve a ser sugerente la provocación lanzada hace dos décadas por Gayle Rubin (1994) cuando, al cuestionar la idea de que la comercialización de la sexualidad es siempre algo negativo, postuló la importancia de una genuina moralidad sexual democrática, en donde lo único combatido en el terreno de las prácticas eróticas, las diferencias sexuales y las relaciones de ese orden sea toda forma de coerción, desigualdad y producción de jerarquías sociales, mientras que la búsqueda del placer propio y del otro conserve intactos su sentido político y emancipado. əo 


\section{BIBLIOGRAFÍA}

Andreas-Salomé, Lou (1998) [1910]), El erotismo. Barcelona, Olañeta.

Badiou, Alain (2011), Elogio del amor. Paris, Café Voltaire Flammarion.

Bajoit, Guy (2012), “Libertad y alienación del individuo contemporáneo”, en Hugo José Suárez, Verónica Zubillaga y Guy Bajoit (coords.), El nuevo malestar en la cultura. México, IIS-UNAM, pp. 31-49.

Bataille, Georges (1988), El Erotismo. Barcelona, Tusquets.

Baudrillard, Jean (1989), De la seducción. Madrid, Cátedra.

Bauman, Zygmunt (2005), Amor líquido. Acerca de la fragilidad de los vínculos humanos. Buenos Aires, FCE.

Bernstein, Elizabeth (2007), Temporarily Yours: Intimacy, Authenticity, and the Commerce of Sex. Chicago, University Chicago Press.

Bordo, Susan (2000), The Male Body: A New Look at Men in Public and in Private. New York, Farrar, Straus and Giroux.

Bozon, Michel (2002), Sociologie de la sexualité. Paris, Nathan.

Butler, Judith (2006), Vida precaria. El poder del duelo y la violencia. Buenos Aires, Paidós.

Clarín (2014), "El sexo le escapa a la crisis y la gente invierte dinero para mantener el deseo", Clarín. Buenos Aires, 23 de noviembre, URL: http://www.clarin.com/sociedad/Sexo-juguetes-pasion-crisisterapias-amor_0_1253874651.html

Collin, Françoise (1991), "Sobre el amor: conversación con Julia Kristeva”, en Debate Feminista, año 2, vol. 4, septiembre, pp. 137-154.

Coria, Clara (2014), El sexo oculto del dinero. Formas de la dependencia femenina. Barcelona, Red. 
Coria, Clara (2011), El amor no es como nos contaron... ni como lo inventamos. Barcelona, Paidós.

Curtis, Debra (2004), "Commodities and Sexual Subjectivities: A Look at Capitalism and Its Desires", en Cultural Anthropology, vol. 19, núm. 1, pp. 95-121.

Elizalde, Silvia (2014), “Aprendiendo a ser mujeres y varones jóvenes: prácticas de investimento de género y sexualidad en la institucionalidad escolar", en Intersecciones en Comunicación, núm 8, Facultad de Ciencias Sociales de la Universidad Nacional del Centro de la Provincia de Buenos Aires, pp. 33-52.

Elizalde, Silvia (2015), Tiempo de chicas. Identidad, cultura y poder. Buenos Aires, Grupo Editor Universitario.

Elizalde, Silvia, Karina Felitti y Graciela Queirolo (2009), Género y sexualidades en las tramas del saber. Revisiones y propuestas. Buenos Aires, Del Zorzal.

Entremujeres (2014a), “Trigasmo: despertá (al mismo tiempo) tres puntos del placer femenino”, Clarín digital. Buenos Aires, URL: http://entremujeres.clarin.com/pareja-y-sexo/sexo/sexo_anal-sexo-orgasmopunto_g-clitoris-trigasmo-placer-estimulacion_0_1075692526.html

Entremujeres (2014b), “Eyaculación femenina: ¿mito o realidad?”, Clarín digital. Buenos Aires, URL: http://entremujeres.clarin.com/pareja-y-sexo/Eyaculacion-femenina-mito-realidad-punto_G-orgasmoplacer-sexualidad_0_440356029.html

Esteban, Mari Luz (2011), Crítica del pensamiento amoroso. Barcelona, Bellaterra.

Felitti, Karina (2012), La revolución de la píldora. Política y sexualidad en la Argentina de los sesenta. Buenos Aires, Edhasa.

Foucault, Michel (2008), Historia de la sexualidad. 1. La voluntad de saber. Buenos Aires, Siglo XXI.

Giddens, Anthony (1998), La Transformación de la intimidad. Sexualidad, amor y erotismo en las sociedades modernas. Madrid, Cátedra.

Gregori, María Filomena (2011), “Mercado erótico: notas conceituais e etnogáficas”, en Adriana Piscitelli, 
Gláucia Oliveira de Assis y José Miguel Nieto Olivar (org.), Gênero, sexo, amor e dinheiro: mobilidades transnacionais envolvendo o Brasil. Campinas, Pagu, Núcleo de Estudos de Gênero, UNICAMP, pp. 461-489.

Hall, Stuart (1984), "Notas sobre la deconstrucción de lo popular", en Raymond Samuels (ed.), Historia popular y teoría socialista. Barcelona, Crítica, pp. 93-109.

Hall, Stuart (2010 [1990]). Sin garantías. Trayectorias y problemáticas en estudios culturales. Popayán, Lima, Quito, Universidad Andina Simón Bolívar, Instituto de Estudios Sociales y Culturales Pensar, Pontificia Universidad Javeriana, IEP, Envión Editores.

Illouz, Eva (2007), Intimidades congeladas. Las emociones en el capitalismo. Buenos Aires, Katz.

Illouz, Eva (2012a), Por qué duele el amor. Una explicación sociológica. Buenos Aires, Katz, Capital Intelectual.

Illouz, Eva (2012b), en entrevista filmada. Podularity.com, consultada el 20 de noviembre de 2014, URL: https://www.youtube.com/watch?v=_zceA9q68WU

Illouz, Eva (2014) Erotismo de autoayuda. Cincuenta sombras de Grey y el nuevo orden romántico. Buenos Aires, Katz, Capital Intelectual.

Jónasdóttir, Anna G. (2011), “What kind of power is “love power”?", en Jónasdóttir, Anna G., Valerie Bryson y Kathleen B. Jones (eds.), Sexuality, Gender and Power. Intersectional and transnational perspectives. New York, Routledge.

Jones, Daniel y Mónica Gogna (2014), “De los médicos pioneros a la explosión del Viagra: medicalización y sexología en la Argentina”, en Agustina Cepeda y Cecilia Rostoyburu, De las hormonas sexuadas al Viagra. Ciencia, Medicina y Sexualidad en Argentina y Brasil. Mar del Plata, Argentina, EUDEM, pp. 139-171.

Kelly, Elizabeth A. (2005), "Review Essay: A New Generation of Feminism? Reflections on the Third Wave", en New Political Science, vol. 27, núm. 2, pp. 233-243.

Kipnis, Laura (2008), Contra el amor. Un ensayo concupiscente. México, Tumbona. 
Kulick, Don (1995), “Introduction: The Sexual Life of Anthropologists: Erotic Subjectivity and Ethnographic Work", en Don Kulick y Margaret Wilson (eds.), Taboo: Sex, Identity and Erotic Subjectivity in Anthropologi-cal Fieldwork. New York, Routledge, pp. 1-27.

Kullock, Paola (2014), "Los hombres son malos amantes porque las mujeres les mentimos", en entrevista a Imneuquen.com.ar. Neuquén, 9 de marzo, consultado el 10 de marzo de 2014, URL: http:// www.lmneuquen.com.ar/noticias/2014/3/9/los-hombres-son-malos-amantes-porque-las-mujeres-lesmentimos_217481

La Nación (2014), "Por qué Julien Blanc es llamado el hombre más odiado del mundo”, en La Nación. Buenos Aires, 14 de noviembre, URL: http://www.lanacion.com.ar/1744052-por-que-julien-blanc-esllamado-el-hombre-mas-odiado-del-mundo

Lopes Louro, Guacira (comp.) (1999), O Corpo educado. Pedagogias da sexualidade. Belo Horizonte, Autentica.

Lorde, Audre (2000), “Uses of the Erotic. The Erotic as Power”, en Drucilla Cornell (ed.), Feminism and Pornography. Nueva York, Oxford University Press, pp. 569-574.

Maines, Rachel P. (2012), Technologies de l'orgasme. Le vibromasseur, "l'hystérie » et la satisfaction sexuelle des femmes. Paris, Payot \& Rivages.

McCaughey, Martha y Christina French (2001), "Women’s Sex-Toy Parties: Technology, Orgasm, and Commodification”, en Sexuality and Culture, vol. 5, núm. 3, pp. 77-96.

McRobbie, Angela (2009), The Aftermath of Feminism. London, Sage.

Morgade, Graciela (coord.) (2011), Toda educación es sexual. Buenos Aires, La Crujía.

Muchembled, Robert (2008), El orgasmo y Occidente. Una historia del placer desde el siglo XVI a nuestros días. Buenos Aires, FCE.

Preciado, Beatriz (2011), Manifiesto contrasexual. Barcelona, Anagrama. 
Rubin, Gayle y Judith Butler (1994), “An Interview: Sexual Traffic”, en Differences: A Journal of Feminist Cultural Studies 6 (2-3), pp. 62-99.

Simonis, Angie (2012), "La diosa feminista. El movimiento de espiritualidad de las mujeres durante la segunda ola”, en Feminismo/s 20. Centro de Estudios sobre la Mujer de la Universidad de Alicante, diciembre, pp. 25-42.

Snyder, Claire R. (2008), "What Is Third-Wave Feminism? A New Directions Essay”, en Signs, vol. 34, núm. 1, pp. 175-196.

Sordo, Pilar (2013), Lecciones de seducción. Una reflexión profunda desde nuestro costado más íntimo. Buenos Aires, Planeta.

Storr, Merl (2002), “Classy Lingerie”, en Feminist Review, núm. 71, pp. 18-36, doi:10.1057/palgrave. fr.9400032.

Storr, Merl (2003), Latex and lingerie: shopping for pleasure at Ann Summers. Oxford, New York, Berg.

Vigarello, Georges (2005), Historia de la belleza. El cuerpo y el arte de embellecer desde el Renacimiento hasta nuestros días. Buenos Aires, Nueva Visión.

Viveros, Mara (2009), "La sexualización de la raza y la racialización de la sexualidad en el contexto latinoamericano actual", en Revista Latinoamericana de Estudios de Familia, núm. 1. Colombia, Universidad de Caldas, pp. 63-81.

Wacquant, Loïc (2006), Entre las Cuerdas. Cuadernos de un aprendiz de boxeador. Buenos Aires, Siglo XXI.

Weeks, Jeffrey (1993), El malestar de la sexualidad. Significados, mitos y sexualidades modernas. Madrid, Talasa.

Workman, Nancy V. (1996), "From Victorian to Victoria's Secret: The Foundations of Modern Erotic Wear”, en The Journal of Popular Culture, vol. 30, núm. 2, pp. 61-73. 


\section{PÁGINAS WEB CONSULTADAS (ÚLTIMA FECHA DE CONSULTA: 16 DE MARZO DE 2015)}

Coaching de seducción, URL: http://coachingdeseduccion.com.ar

La Caja de Grey, URL: http://www.lacajadegrey.com

Levantartseduccion, URL: http://www.levantartseduccion.com

Pimpingmygame, URL: http://www.pimpingmygame.com

PK escuela de sexo, URL: http://www.pkescueladesexo.com.ar

Poledanceschool, URL: http://www.poledanceschool.com.mx

Seduccionsecreta, URL: http://www.seduccionsecreta.com.ar

SexpoErótica, URL: http://www.sepoerotica.com.ar

Tentarte, URL: http://www.tentarte.com.ar

Vixen workout, URL: http://www.vixenworkout.com

\section{REGISTRO ETNOGRÁFICO}

Notas de campo (2013a), Taller Intensivo de Seducción y Strip, Tentarte, octubre y diciembre. Buenos Aires.

Notas de campo (2013b), Taller especial de seducción, $P K$, noviembre. Buenos Aires.

Fecha de recepción: 26 de noviembre de 2014

Fecha de aceptación: 7 de abril de 2015 